\title{
A Case Study of Employees’ Engagement Practice in Corporate Responsibility Program
}

\author{
Fadzlina Mohd Fahmi, Izam Zuliana Yahya \\ Universiti Teknologi MARA, Puncak Alam, Selangor, Malaysia
}

\begin{abstract}
Organizational corporate social responsibility is a good practice by organizations. Organizations engagement in corporate social responsibility programs may benefit the organization and stakeholders. The focus of this paper is to explore the extent of employees' engagement in the organization's corporate responsibility programs by utilizing Unerman's (2007) stakeholders engagement framework. The main research question is how employees engage themselves in corporate social responsibility programs. This study employs a case study research design approach. The findings have shown that there is empowerment between employees and the management in the corporate social responsibility programs. Their involvement appears from their feedbacks and views in the surveys as well as discussion with regards to corporate responsibility programs. All in all, employees' engagement is seen as an important practice in the organization, particularly in planning, implementing, monitoring, and reporting the corporate responsibility program.
\end{abstract}

Keywords: corporate responsibility program, stakeholders engagement, employees engagement, empowerment, a case research design approach, Malaysia

\section{Introduction}

In today's corporate agenda, corporate social responsibility has been recognised as one of the important elements in most organizations. The effectiveness of contributions and social obligations exposed through corporate social responsibility or commonly known as CSR can lead to better development in terms of social environment and economy for nations, societies, and communities around the world. Corporate social responsibility is about how a company aligns its business operations towards economic, environment, and social aspects (Ismail, 2009). CSR supports the organization by creating a balance in business practices by considering elements such as environmental aspects, apart from providing a positive impact on corporate reputation and profitability (Khojastehpour \& Johns, 2014). Thus, the implementation of CSR requires effective approaches that can bring about positive outcomes to beneficiaries such as customers, suppliers, employees, and organizations. The stakeholders' expectations can be realized when they can enjoy the benefits direct or indirect effects from the organizational CSR activities (Anthony \& Hong, 2014). As such, the relationship

Fadzlina Mohd Fahmi, senior lecturer, Faculty of Accountancy, Universiti Teknologi MARA, Puncak Alam, Selangor Darul Ehsan, Malaysia.

Izam Zuliana Yahya, student, Faculty of Accountancy, Universiti Teknologi MARA, Puncak Alam, Selangor Darul Ehsan, Malaysia.

Correspondence concerning this article should be addressed to Fadzlina Mohd Fahmi, Faculty of Accountancy, Universiti Teknologi MARA, Puncak Alam Campus, 42300, Puncak Alam City, Selangor Darul Ehsan, Malaysia. 
between the stakeholders and the organization is important in building a strong organizational CSR. Kakabadse (2005) argued that effective stakeholder management approach is a good mechanism to establish short- and long-term CSR performance. Through strong relationship, stakeholders would have the opportunities to engage themselves in the CSR programs as part of the sustainable business practices. Engagement here refers to their involvement in CSR programs in terms of reporting and decision making process, in particular, the stakeholders' participation or involvement in the execution of the CSR programs. Hereafter, in the context of this study, CSR will be addressed as "corporate responsibility" to suit with the concept of the case study.

It is important for the organization to value the needs of the stakeholders as their contribution is significant to the growth of the organization. Drieniková and Sakál (2012) claimed that stakeholders' need is not achieved merely through general identification and classification but need to be related to the involvement of the stakeholders in decision making process of the organizational corporate responsibility programs. Therefore, effective mechanisms need to be fostered between stakeholders and the organization in all related aspects. The organization may establish the relationship between the stakeholders and the organization through the joint process of negotiation, intensive dialogue, and consistent commitment (Moriarty, 2006).

Employee is one of the organization's stakeholders. It is important to manage their expectation and needs which can be done through their engagement in the organization's CSR. Employees are happy when the organizational social activities are able to cater their needs and expectations. For example, improvement of employees' benefits in kind through internal corporate responsibility program may facilitate a higher level of motivation among the employees (Skudiene \& Auruskeviciene, 2012), and therefore enhance organizational success. However, the organization can only achieve this if they know what are their employees' needs and desire. This could only be done through an engagement practice, particularly in corporate responsibility programs relating to their career development and social activities. Therefore, this study seeks to explore the extent of employees' engagement in organizational corporate responsibility programs through their direct or indirect involvements. These involvements can be viewed in a form of involvement in decision making process, being part of event committees, giving feedback through email and survey or even contributing through participation in the programs. The employees' involvement is important as their participation shall determine the failure or the success of the corporate responsibility programs held. As Boyd and Gessner (2013) argued that the performance system implemented by the human resource department should not only focus on the organization's goals and interests alone but should also express care to the employees' needs and expectations. The most effective system can be established when the management and employees are able to team up together in creating a great social organizational culture. The management's top-down approach towards effective internal and external outcomes for the employees will produce strong elements of corporate responsibility in the organization (Bhattacharya, Sen, \& Korshun, 2008). The remainder of the paper is structured as follows: the next section presents the literature review (including discussion of the framework). It is followed by the research design and methodology. Then, the analysis of findings and conclusions are then described.

\section{Literature Review}

\section{Corporate Social Responsibility and Stakeholders}

In common acknowledgement, the stakeholders generally refer to employees, customers, suppliers, communities, and shareholders. The stakeholders are important groups involved directly and indirectly in contributing to the development of the company. The relationship between the organization and the 
stakeholders not only can be established mainly through monetary aspects alone, but also can be channeled through the CSR initiatives. It is important for organization to implement the CSR practices wisely so that they can fulfill the stakeholders' needs respectively as their needs will yield significant changes and development to the organization. Drieniková and Sakál (2012) claimed that stakeholders' needs are not achieved merely through general identification and classification but need to be adhered closely through involvement of the stakeholders in decision making of CSR process. These needs can be achieved when the stakeholders themselves are given the opportunities to contribute in the organization. Organization may establish value creation between the stakeholders and the organization through the joint process of negotiation, intensive dialogue and consistent commitment (Moriarty, 2006). The collaboration will enhance the satisfactions and understanding between both parties in short- and long-term periods.

The fulfillment of the stakeholders' needs will enable the initiation of a great foundation between the stakeholders and the organization in moving forward successfully with best sustainable practices. Effective communication between company and its people can enhance the responsibilities that company holds towards meeting the serious obligation it assumes in achieving the ideal economic and environmental performance within the company and the society (Kakabadse, 2005). Evans and Sawyer (2010) claimed that effective management practices and initiatives in CSR will lead to fruitful impacts to the environment, community, and the employees as well as for the benefit of their business. While Azada and Rochte (2013) highlighted that the integrity and alignment between the managers and employees can fulfill the corporate and employee goals, thus will streamline the positive development seen in the organization as a whole.

Despite the pursuit to fulfill stakeholders' need through CSR, communication gap and dissatisfaction can create opposite circumstances between stakeholders and the organization due to the inevitable challenges that they have to face. These challenges which include those in operational, institutional, and physical elements can influence the management to conduct unbalanced engagements in CSR (Katamba, Kazooba, Mpisi, Nkiko, Nabatanzi, \& Kekaramu, 2012). The resulting distractions may stop the organization from satisfying stakeholders' needs through CSR. For instance, due to management's negligence in achieving the employees' needs such as through attractive salary package and career development opportunities, employees can become demotivated and dissatisfied with the management. Consequently, the relationship between both parties will be jeopardized and this in turn will affect the entire business operations. Therefore, the organization should tackle the challenges efficiently in order to protect their CSR position as well as the stakeholders' need. Bhattacharya et al. (2008) found that management's top-down approach towards effective internal and external outcomes for the employees' satisfaction will produce strong elements of CSR in the organization. The close monitoring of internal CSR and employees' internal motivation can encourage the management to practically resolve the dilemmas by focusing on some areas of CSR (Skudiene \& Auruskeviciene, 2012). Boyd and Gessner (2013) on the other hand argued that the metric system that is based on the management assessment alone is only focused on the organization's goals and interests; hence the partnership based on system is more applicable by considering employees' involvement in the performance metrics. Therefore, a good working cycle in an organization between company and stakeholders is essential to be carried out accordingly without any hassles. CSR programs thus can be carried out successfully when all stakeholders' needs are met.

\section{Corporate Social Responsibility and Employee}

Employees' responsibilities do not only lie on the regular day-to-day tasks but also other duties that can 
result to direct and indirect contributions including through the CSR programs organized by their organization. Employees are influenced to engage themselves in their company's activities when the company is able to create the engaging environment with care and respect to the employees (Carnegie, 2012). CSR can enhance employee's integrity and motivation towards their intentions and increase willingness to contribute to the organization. Employees can be influenced to be more committed towards their work as well as their social obligation when their organization achieves higher reputation and is more involved through interventions in CSR (I. Ali \& J. F. Ali, 2011). Finding by Nejati (2013) has also highlighted that employees are more committed if they work in a socially responsible company. When employees are passionate towards their work due to the great contribution given by their company, they will then make positive improvement in productivity and increase their commitment. Skudiene and Auruskeviciene (2012) further explained that the employees are more emotionally engaged to the organization due to their internal motivation grasped through sense of belonging and trust. The presence of employees' engagement can be attached with their contribution in decision making and reporting regardless of the type of CSR activities initiated. Employees' engagement in decision making can help the organization to understand more the desires and thoughts of its staff, thus help the company to produce better approaches and policies (Michael, 2013). Nevertheless, employees need to be exposed genially in the events that require their involvement in the company's activities. Their engagement with the company's activities will get them closer to the company and enhance the sense of belonging to the company. Organizations should be able to create a workforce that is open and honest, shares ideas, can be flexible and adaptive, and engages with and embraces the challenges it faces (Kissida, 2007). It is important for the decision maker to regulate their employees in relation to its policies in order to maintain their loyalty and enhance their contribution to the company (I. Ali, Rahman, S. I. Ali, Yousaf, \& Zila, 2010).

The success of CSR through employee's engagement should be strongly supported by the management team of the company. Inyang and Enuoh (2011) highlighted the importance of human resources role in ensuring the success of CSR concepts and implementations through effective initiatives and practices among the employees and other stakeholders. The role refers to how the human resource team is able to establish strong employee engagement and commitment from other stakeholders that shall sustain better strategic management in the organization. The study by Abugre (2014) revealed that strong managerial leadership can produce effective management input, thus create effective CSR practices and cultures.

Other than the role played by the human resource team, employees' engagement can be influenced by the reactions or feedbacks from the management as well. The employees' engagement can be driven due to the care and interest shown by their managers about their life and well-being (Carnegie, 2012). The management can improve employees' engagement in aspects of skills and opportunities by emphasizing the accelerated coaching and career support, recognition, and accountability into their managerial actions (Baumruk et al., 2006). After all, the employees may feel appreciated when their voluntary engagement in CSR activities is supported and recognized by the management.

\section{Stakeholders Engagement Model}

The first stage relates the motives for implementing the Social and Environmental Reporting (SER) and CSR. The motives refer to the aim or the purpose of the organization for implementing the SER and CSR. There are two broad motives being highlighted in this stage. The first motive is for transforming the organization into environmentally and socially sustainable business practice, whereby the organization's operation does not only 
focus on the financial performance alone. The sustainable development (or corporate responsibility in this context) can be better established through good composition of stakeholders network (internal and external factors) and the organization's expected outcomes (Rhodes, Bergstrom, Lok, \& Cheng, 2014). The other motive is to gain and hold support from the respective stakeholders who have power to influence the organization's performance and achievement, particularly for profit maximization. The change of corporate culture and the CSR strategies gives positive impact to the firm's performance in financial terms (Moneva, Rivera, \& Muñoz, 2007).

The second stage refers to "who", the identification of the stakeholders who are mainly involved in achieving the desired motives of SER and CSR. Among the list of stakeholders, the organization needs to determine suitable stakeholders that would directly engage the motives of the organizational SER and CSR. Ditlev-Simonsen and Wenstøp (2013) found that the different perceptions and organizational culture relate to different rank of stakeholders and these would become the main motivators in engaging the CSR.

The third stage elaborates "for what" the identified stakeholders need to engage in SER and CSR. The engagement relates to the social environment and economic expectations and needs from these stakeholders. The expectations will indicate the type of behaviors that are required by the stakeholders as well as the information needed in order for them to evaluate the organization's performance in SER and CSR. The stakeholders' evaluation will determine whether their expectations are met or not.

The last stage relates to how the stakeholders' expectation and information needs are compiled. It is important for the organization to implement capable approaches in order to ensure that adequate information is gathered from the stakeholders' engagement and that they can yield effective results for the social and environmental reporting as well as CSR. The multi-faceted web technologies can be a good communication strategy that can bring the company into closer interaction with a broader group of stakeholders with regards to the CSR performance (Adams \& Frost, 2006).

Table 1

Unerman's (2007) Stakeholder Engagement Framework

\begin{tabular}{|l|l|}
\hline Stage in model & Issues determined in stage \\
\hline 1. Why & Motives for social and environmental reporting (SER) and CSR \\
\hline 2. Who & Range of stakeholders to be addressed in SER \\
\hline & Determining responsibilities, and information needs of, stakeholders through engagement and dialogues \\
\hline 3. For what & \\
\hline 4. How & Mechanism used to compile and communicate reports addressing these stakeholders' information needs \\
\hline
\end{tabular}

Source: Stakeholder engagement framework (Unerman, 2007, p. 89).

\section{Research Design and Methodology}

The case study was selected as the research approach for this study. The case study is viewed as a suitable research strategy due to its easy approach as "when" and "how" questions can be created with less control over the event and when the focus is on a contemporary phenomenon within some real-life context (Yin, 2003). Meyer (2001) emphasized that the case study approach gives more room to tailor, the research design, and data collections procedures to the identified research questions. Through the comprehensive comments and views 
obtained from the interviewees, the case study approach would be able to provide deep understanding on how effective employees' engagement is in corporate responsibility programs.

For the purpose of the study, Delta Berhad was chosen as the organization investigator. The selection was made due to its solid corporate position that is one of the leading arms in Malaysia, not only in business operations but also in corporate responsibility (Annual Report Year 2013, p. 30). Delta Berhad operates in three sectors, namely in service, automotive and as well as in the property, assets, and construction sector. Among the three sectors under Delta Berhad, the property, assets, and constructions (hereafter, PAC) sector was chosen as the unit of analysis due to its higher number of employees among all sectors (Annual Report Year 2013, p. 89). Thus, the information gathered in regards to employees' engagement practices in PAC sector would give a better insight and clarification to the findings of the study. Hereafter, the property, asset, and construction sector will be addressed as PAC sector. The preliminary stage of the research was initiated with the identification of the divisions in PAC sectors that are closely responsible in implementing corporate responsibility programs. The Corporate Affairs, Communications and Branding division and Human Capital Development division were identified to play important roles in planning and executing corporate responsibility programs in PAC sector. Hereafter, the Corporate Affairs, Communications and Branding division will be addressed as CCB division while Human Capital Development division as HCD division.

Table 2

List of Interviewees

\begin{tabular}{ll}
\hline Position & Department \\
\hline Executive A & HCD \\
Executive B & HCD \\
Manager & HCD \\
Senior manager & HCD \\
Manager & CCB \\
\hline
\end{tabular}

The heads of both divisions were approached through emails. They then provided the list of interviewees, whereby the interview sessions were conducted with the respective managers and executives in both divisions. The respective staffs and managers selected were among those who are directly attached with employees' engagement in corporate responsibility activities and who also are responsible in the decision making and reporting process in the PAC sector's corporate responsibility programs. In total five interviews were conducted (see Table 2 above). For the purpose of the study, the main data collection strategy is semi-structured interviews. However, multiple methods of collecting evidence were used to corroborate findings from the interview data including document reviews. The interview sessions of this study were conducted with 25 questions covering the respondents' understanding of corporate responsibility, implementation of corporate responsibility programs, employees' engagement in corporate responsibility programs and reporting, procedures and guidelines on corporate responsibility and lastly, the challenges in implementing the corporate responsibility. Interviews questions are formulated based on several broad themes such as (i) implementation of corporate responsibility programs, (ii) motivation of corporate responsibility programs, (iii) structure of corporate responsibility programs, (iv) corporate responsibility programs' monitoring and reporting, and (v) employees' engagement in corporate responsibility programs and reporting. The interview sessions were conducted in English language and lasted from 30 minutes to 120 minutes. The 
recorded interview quotes were then transcribed accordingly in order to carry out data interpretations. Since the process is done manually, the transcriptions were done carefully in order to sustain the accuracy of the data.

\section{Findings and Discussion}

The findings and discussion section below follows the Unerman's (2006) framework which starts with the identification of the broad motivations of corporate responsibility programs, then follows with the linking of stakholders identification to the motivation of the corporate responsibility programs. Then, stakeholders' needs are identified through the stakeholders engagement and dialogue process. Finally the mechanisms used to compile and communicate the report are then described.

In general, the implementation of corporate responsibility programs in Delta's Berhad is influenced by the “Bursa Malaysia” CSR Framework. "Bursa Malaysia” enforced all public listed companies to comply with the framework or CSR guidelines which emphasized on four main areas of CSR such as market place, community, workplace, and environment. This can be seen clearly in the annual report 2013 which reported that the programs were implemented according to the guidelines given. The disclosures are based on the holistic programs from their three sectors which are the PAC sector, automotive, and service sector. Delta Berhad has remarked the impressive social contributions that have given the positive changes and developments to the local and global environment, market place, employee, and also the community. Each area has been elaborated accordingly into various concepts and practices of corporate responsibility, which are able to cater the good corporate conduct (Annual Report Year 2013, p. 129). The CCB Manager also commented that:

Every sector is being looked into, like environment you need to ensure the company are sensitive towards preserving the needs of mother nature, so you know when you do recycling program, you do not simply do open burning, or you build a building instead of you plant something, you have the balance corporate responsibility programs when you fulfill the four elements market place, community, workplace, and environment.

The above quotes illustrate that Delta corporate responsibility programs are encompassing four elements of the CSR framework by the "Bursa Malaysia". This indicates that Delta's broad motivation of implementing the corporate responsibility is aligning into transforming its business practice by taking into consideration of social, economic, and environmental aspects in the four elements such as market place, community, workplace, and environment. Thus, this reflects that their business practice is held responsible and accountable for all stakeholders, and not for only for specific stakeholders (for example, only shareholders which particularly have interest on the organization's profit) (Gray, 2006).

Given that PAC sector is one of the Delta's group of companies, the implementation also appears to follow the Delta group corporate responsibility guidelines and practices, that is, market place, community, workplace, and environment. For example, the CCB Manager emphasized that:

My primary job is to coordinate with the respective heads, to ensure all the corporate responsibility activities are executed with the given guidelines, and they have to ensure that four elements market place, community, workplace, and environment properly complied.

He continued,

It has been made compulsory by the Delta group corporate division for each company to engage ourselves in corporate social related activities corporate responsibility programs and we are given specific budget in doing so.

Despite following the guidelines, the above quotes further illustrate that engagement from employees (one 
of the Delta stakeholders) is crucial when implementing corporate responsibility programs. Thus, this also means that stakeholders engagement is one of their motivations for the corporate responsibility programs in Delta, and PAC sector specifically. For example, in order to ensure that the impacts are evenly distributed we come out with the four elements-market place, community, workplace, and environment, to ensure that you have a small fraction of employees' participations via workplace. You always have positive portrayal of the company by making the workplace element is satisfied (CCB Manager).

In a similar vein, CCB Manager had also emphasized that the selection of the corporate responsibility programs is based on the preference and most acceptable by the employees. This is further corroborated with a review of the annual report (2013, p. 127) stating that:

Engaging our people is the crucial success factor for Delta Berhad. Therefore, the group management encourages all divisions and operating companies to embark in creative engagement activities to strengthen working relationships and build team synergy.

The above quote further illustrates that Delta Berhad is committed to ensure that all corporate responsibility programs would be able to serve their employees' (one of their stakeholders) needs and interests and therefore, motivate them to participate in the programs. As a result, the employees in PAC sector would enjoy engaging in corporate responsibility activities thus able to increase their productivity, and therefore fulfill the company's missions and visions. Right (2009) finds that voluntary employees' engagement in CSR may bring positive impact to the management and leaders of the organizations.

Having determined that broad motives of implementing the corporate responsibility programs are: (i) to transform the business practice into social and environmentally responsible, and (ii) stakeholders engagement, therefore, the next process involved is to determine "to whom" the organization needs to report in order to achieve these objectives. Based on the motives of implementing the corporate responsibility programs, Delta's approach of doing the corporate responsibility programs is more holistic, and therefore, it needs to address various types of stakeholders for each area of the corporate responsibility programs. Since the scope of the study is related to employees' engagement, therefore, "workplace” element is the appropriate element to examine the "extent of employees" engagement practice of the organization. Thus, the main stakeholder for "workplace" elements are employees. The employees in PAC sector are significantly involved in programs such as career development, team buildings, and other sport and recreation programs. For instance HCD Manager clarifies that:

No specific criteria for the staffs to join, somehow we will make sure that every staff to get involved in any activities so that they can feel appreciated and carry the duties in their best way. The activities will enable them to get together as such can minimize the gap between them and the management.

The PAC sector has initiated a good foundation of corporate responsibility with employees in programs. In the PAC sector, HCD division also involves in conducting the employees' engagement programs other than CCB division. Though the division is not in the loop of CCB Division, the HCD division also conducts various programs which relate to employees such as sport and recreation activities, team buildings, breakfast with the Chief Operating Officer as well as staffs' training and developments activities. From the interviews with the HCD team, it appears that the division considers on the employees' needs and preference when designing the corporate responsibility programs.

Since the HCD division involves directly in planning and implementation of the corporate responsibility program in most companies in PAC sector, the arrangement of the programs is based on its own concepts and 
practices which focus on employees' welfares. The Senior Manager of HCD division emphasized that the corporate responsibility program in PAC sector is not only in charge by the CCB division but also taken care by his department or directly from the company's management. Based on the interviews, it appears that the implementation of corporate responsibility program in PAC sector has more emphasized on the benefits to the employees and therefore following the CSR Framework of "Bursa Malaysia”. Bauman and Skitka (2012) argue that CSR can affect the relationship between employees and employers through four distinct paths namely as four universal psychological needs: security, self-esteem, belongingness, and a meaningful existence. Hence, the continuous corporation existed between the employers and the employees through the corporate responsibility programs can strengthen the relationship between the employees and the management team in the company. In turn, this may ensure achievement of the organizational objectives.

Stakeholders' engagement and dialogues are important to identify the stakeholders' interests and needs. In PAC sector itself, the corporate responsibility programs require a lot of engagement from the employees in a form of direct and indirect engagements in the corporate responsibility programs. The HCD team will get employees' views and feedback on the programs. For instance, the Senior Manager of HCD division highlighted:

It is just a casual chat or discussion with them, ask them for the comments or feedback of the activities, so from there we do the evaluation.

Similarly, HCD Executive (B) had this remarked:

Base on response and feedback through email that can give inputs and improvement to us for planning and executing the programs, some may need them to be the committee as well so they involve in giving ideas as well.

From the feedbacks and views from employees, the HCD division will proceed with the proposal of the selected corporate responsibility programs to the management for approval. This means that employees in PAC sector involve in the decision making process in determining what programs to be implemented. The HCD Manager had this view:

For me, they do involve in decision making "indirectly" because their feedback, their response determine our next steps to proceed or not with the programs. Their response will initiate our decision to carry out the programs or find other option. Whatever suggestions or comments from them, we will highlight to the management.

Employees are not only involved in making decision on the CR program but also aspects of training development. They are required to give list of trainings that they would like to attend, and after that only HCD division will finalize the training lists based on the majority request by the employees and also the company's needs. Other than that, the HCD division also gives the opportunity for the employees to be part of decision making process whereby the employees are appointed to be part of the program's committee team. The closer employees' engagement can be initiated in the programs when the employees are given duties to coordinate the programs. For instance, Senior Manager of HCD emphasized that:

Once the project has been approved, we will revert to the company to get one representative of the employees to become the committee member, and the committee member with start planning with the whole team to execute the program.

Based on the above findings, PAC sector successfully implements the engagement and dialogues with the stakeholders, particularly the employees. This further indicates that employees' inclusivity is quite in PAC sector apparent particularly in making decision with regard to the programs. 
The employees in PAC sector do not involve in preparing the corporate responsibility report, but their involvements through giving feedbacks and suggestions are useful in the reporting process. The employees' engagement in the reporting process can be attached when their feedbacks through surveys and questionnaires are being used for the reporting process. Their views and comments should be able to validate the effectiveness of the corporate responsibility programs. The HCD division has also adopted the employees' evaluation in their reporting process such as training evaluation form for pre and post of training programs. The HCD Executive (B) emphasized that the employees' information shall support the HCD division to conduct analysis on the employees' career development.

However, the challenges faced by the management in getting the information will distract the decision making and reporting process. The interviewees confirmed that, some employees are selective and reluctant for some of the corporate responsibility programs thus the responses received from them are low. For instance, the HCD Executive (B) mentioned that if no feedback given by the employees will cause them not to proceed with the program. While CCB Manager explained:

The problem with the company when we organize something is we do not get great feedback because sometimes they do not feel comfortable to be participating in the activities. We need to bring these people in, so the challenge again is what kind of activities that can predominately attract people.

The HCD Manager also remarked:

The challenges can be actually from the employees. For staffs, the challenges are the responses in terms of attendances and participations in the programs. If no response or low participation from staffs then the programs can be cancelled off.

While HCD Executive (A) highlighted that:

Our challenge or issues are about when we need to communicate with staffs, so the most difficult thing when we communicate with staffs that don't want to corporate with us. For senior staffs that they don't train are important and required by them because they are already old/veteran but somehow all challenges we still can handle it.

Despite facing such challenges, the management is still able to execute the corporate responsibility programs based on the majority supports from the employees thus still able to produce the effective sustainability report. The challenges have led CCB and HCD divisions to be more alert of the selection of the corporate responsibility activities in order to ensure all employees give their full support. However, in terms of selection of type of activities to be included in the calendar year, HCD division does not put the compulsory need upon the selection of category as long as the employees enjoy themselves and get benefit from it. On the other hand, the CCB division needs to fulfill the group's requirements whereby any sort of corporate responsibility programs should cover all four elements. The employees' engagement programs will be categorized as "workplace" element. Hence the programs need to be achieved at the stated range figures regardless of any type of engagement programs with the employees.

In summary, the empowerment exists through two ways of communications between the employees and the management team. The employees of PAC sector are given the opportunity to engage in the corporate responsibility program whereby their ideas and feedbacks are considered in the implementation of the corporate responsibility programs. The top-bottom communication approach adopted in PAC sector can enhance the effectiveness of corporate responsibility programs and reporting. However, the PAC sector needs to provide 
more awareness and support to the employees in contributing more thus enhancing their engagements.

The two divisions need to correlate together in planning, implementing and monitoring the corporate responsibility programs hence creating the better engagement system between the employees and the organization. Consequently the good norm of employees' engagement in the PAC sector of Delta Berhad shall be the good model for other sectors in Delta Berhad as well other corporate entities.

\section{Conclusion}

From the case study, it has shown that employees play the important roles in the corporate responsibility in PAC sector through their engagement in corporate responsibility programs and reporting. The extent of their engagements has managed to influence the implementation of corporate responsibility programs and reporting in the PAC sector. In the pursuit to meet their needs and expectation, the employees engage in the corporate responsibility program when they are given the opportunity to be the committee members of the programs. The involvement would enable them to be part of the decision making team and process in the committees. Other than that, the employees' feedbacks and views through surveys and questionnaires are also the mechanisms for them to engage in implementation of the corporate responsibility programs and reporting process. This is where the management of CCB division and HCD division is able to analyze and monitor the corporate responsibility programs when they produce the sustainability report and the internal report. These have shown that the empowerment exists through two ways of communications between the employees and the management team. It appears that the top-down approach can enhance the effectiveness of corporate responsibility programs and reporting in the PAC sector. Better collaboration between the management team and employees would enhance the employees' engagement in achieving their needs and expectations and the overall performance of the company.

\section{References}

Ali, I., \& Ali, J. F. (2011). Reputation and employee engagement. Personal, M., Archive, R., 33891. 1-17.

Ali, I., Rehman, K. U., Ali, S. I., Yousaf, J., \& Zia, M. (2010). Corporate social responsibility influences employee commitment and organizational performance. African Journal of Business Mangement, 4(12), 2796-2801.

Anthony Wong, I., \& Hong Gao, J. (2014). Exploring the direct and indirect effects of CSR on organizational commitment. International Journal of Contemporary Hospitality Management, 26(4), 500-525.

Azada, C. J., \& Rochte, M. (2013). Workforce for good employee engagement in CSR/sustainability. White Paper, 1-20.

Baba Abugre, J. (2014). Managerial role in organizational CSR: Empirical lessons from Ghana. Corporate Governance: The International Journal of Business in Society, 14(1), 104-119.

Baumruk, R., \& Gorman, R. E. (2006). Why managers are crucial to increasing engagement. Strategic HR Review. 5(2), 24-27.

Bhattacharya, C. B., Sen, S., \& Korschun, D. (2008). Responsibility to win the war for talent using corporate social responsibility. MIT Sloan Management Review, 5(3), 37-44.

Boyd, N., \& Gessner, B. (2013). Human resource performance metrics: Methods and processes that demonstrate you care. Cross Cultural Management: An International Journal, 20(2), 251-273.

Carnegie, D. (2012). What drives employees' engagement and why it matters. Dale Training White Paper, 2-6.

Ditlev-Simonsen, C. D., \& Wenstøp, F. (2013). How stakeholders view stakeholders as CSR motivators. Social Responsibility Journal, 9(1), 137-147.

Drieniková, K., \& Sakál, P. (2012). Respecting stakeholders and their engagement to decision making—The way of successful corporate social responsibility strategy. Research Paper, 165-173.

Evans, N., \& Sawyer, J. (2010). CSR and stakeholders of small businesses in regional South Australia. Social Responsibility Journal, 6(3), 433-451.

Gray, R. (2006). Social, environmental and sustainability reporting and organizational value creation? Whose value? Whose creation? Accounting, Auditing, and Accountability Journal, 19, 793. 
Inyang, B. J., Awa, H. O., Harcourt, P., \& Enuoh, R. O. (2011). CSR-HRM nexus: Defining the role engagement of the human resources professionals. International Journal of Business and Social Science, 118-126.

Ismail, M. (2009). Corporate social responsibility and its role in community development: An international perspective. Journal of International Social Research, 2.

Kakabadse, N. K. (2005). Corporate social responsibility and stakeholder approach: A conceptual review. International Journal Business Governance and Ethics, 1(4), 277-299.

Katamba, D., Kazooba, C. T., Mpisi, S. B., Nkiko, C. M., Nabatanzi-muyimba, A. K., \& Kekaramu, J. H. (2012). Corporate social responsibility management in Uganda lessons, challenges, and policy implications. Internal Journal of Social Economics, 39(6), 375-390.

Khojastehpour, M., \& Johns, R. (2014). The effect of environmental CSR issues on corporate/brand reputation and corporate profitability. European Business Review, 26(4), 330-339.

Meyer, C. B. (2001). A case in case study methodology. Field Methods, 13(4), 329-352.

Michael, A. D., \& Horsford, I. (2013). Active employee participation in the public service decision making process: A public servant perspective. Journal of Business Ethics,7(2), 36-43.

Moneva, J. M., Rivera-Lirio, J. M., \& Muñoz-Torres, M. J. (2007). The corporate stakeholder commitment and social and financial performance. Industrial Management \& Data Systems, 107(1), 84-102.

Moriarty, B. (2006). Company stakeholder responsibility: A new approach of CSR. Business Roundtable Institute of Ethics, 4-9.

Nejati, M. (2013). Corporate social responsibility and organizational commitment. Journal of Global Responsibility, 4(2), 263-275.

Rhodes, J., Bergstrom, B., Lok, P., \& Cheng, V. (2014). A framework for stakeholder engagement and sustainable development in MNCs. Journal of Global Responsibility, 5(1), 82-103.

Right, B. (2009). Corporate social responsibility. The Magazine Wold at Work, 3, 22-25.

Skudiene, V., \& Auruskeviciene, V. (2012). The contribution of corporate social responsibility to internal employee motivation. Balthic Journal of Management, 7(1), 49-67.

Spitzeck, H. (2009). Organizational structures and processes: The development of governance structures for corporate responsibility. The International of Business in Society, 9(4), 55-72.

Unerman, J., \& Bennett, M. (2007). Stakeholder engagement and dialogue. Sustainability Accounting and Accountability, 86-103. Routledge.

Yin, R. K. (1993). Application of case study research. Newbury Park: Sage Publication. 